\title{
Innovative Practices in Teaching and Learning
}

\author{
Durairaj. S. ${ }^{1}$ \\ ${ }^{1}$ Professor /EEE, Principal, Kings College of Engineering, \\ Thanjavur, Tamilnadu, India \\ ${ }^{1}$ rajsdr@rediffmail.com
}

\begin{abstract}
Despite the efforts aiming for attaining quality in Technical Education, Academic Institutions still has a challenge in producing competent Engineering graduates. It is the responsibility of Academic providers and other stake holders to support the process of providing skill based education through innovative practices blending classroom teaching augmented by e-learning resources, high importance to applying the concepts learnt through project works, In-Housing training programme. Affirmative step towards student centered learning shall be encouraged. Project based learning will strengthen technical skills and thereby adding quality in Technical Education. Even distribution of theoretical and practical knowledge is essential to bridge academic-industry gaps. This paper discusses about the need for quality education, approaches that can encourage quality, skills in imparting knowledge.
\end{abstract}

Keywords-Project Based Learning, Student Centered Learning, Industry-Institute interaction.

\section{Durairaj. S. ${ }^{1}$}

${ }^{1}$ Professor /EEE, Principal, Kings College of Engineering, Thanjavur, Tamilnadu, India

${ }^{1}$ rajsdr@rediffmail.com

\section{Introduction}

Engineers who used to dream of white collar jobs, are now concerned about finding decent openings as they get into their final year study. Most of the Engineering graduates who fail to grab an employment in respective industry, end up in joining a BPO or Call Centre. The fact, however remains that $20-33 \%$ out of 1.5 million Engineering graduates passing out every year run the risk of not getting a job at all.

Whether it is supply far out numbering the demand or below-par quality education that is offered, we still have a long way to do and push an agenda into our practices to produce globally competent human resources in the fields of Engineering.

The thirst and growing desire for attainment of technological competence has paved the way to identify approaches which will help students to get acquainted with the required skills.

\section{Role off Technical Education}

Technical Education plays a vital role in creating skilled manpower to sustain Nation's productivity. Our Country has made rapid progress in Engineering Education through institutions springing up like wild mushrooms and their number has gone up high i.e.,3,345 numbers in 2014-15.

However, that does mean that our technical education is on par with the best in developed Countries.

Indian Institutes of Technology are apex institutions for engineering education and research. At present, there are sixteen Indian Institutes of Technology (IITs). Five Indian Institutes of Technology (IITs) are ranked among the top 20 universities in the recent ranking of the top 100 universities of BRICS member nations. The main reason for this position are: IITs impart world class education in engineering and technology; conduct research in the relevant fields, and further advancement of learning and dissemination of knowledge. These Institutes are also contributing significantly to education and research in basic sciences and humanities.

There are many engineering colleges that also provides world-class education. Their graduates are highly sought after by prestigious companies. There is a growing 
concern over acquisition of lifelong skills enhancing knowledge, attitude that will help engineering graduates to meet expectations. These skill are imperative to flourish in occupation, higher studies and to involve in research activities.

\section{Quality in Education}

Quality in Education is defined as "Development of intellectual skills and knowledge that will equip graduates to contribute to society through productive and satisfying engineering careers as innovators, decision makers and leaders in the global economy"[1].

\section{A. Need for Student Centered Learning}

Being innovative is about looking beyond what we currently do well, identifying the great ideas of tomorrow and putting them into practice. It is the responsibility of the educational institutions to provide unlimited academic possibilities by an active learning environment for the student community.

Teaching at Technical institutions, mostly, concentrates on giving information which is not the sole objective of Teaching. An engineer should possess skills to develop:

- Understand and apply the concept

- Reasoning and critical thinking

- $\quad$ Self-learning habits and thirst for life-long learning

- Decision making skills

- Risk taking capacity, scientific temper, etc.

Further, mere lecture based teaching alone does not have potential of achieving the above mentioned objectives. The objectives are multi-dimensional in nature, so for their achievement multiple methods should be used in an integrated fashion.

In the light of this, it is important to reflect on StudentCentered Learning and focus on practical learning thereby we can promote good (and even memorable) learning experiences for the students.

\section{B. Learning theories and educational strategies}

Thinking in 'Student-centered' terms should be at the heart of our educational efforts. While being concerned with implementing a teaching and learning environment that puts the students' experience at the centre, we need to build fundamental research and strong pedagogical bases. Moreover, teaching/learning have been traditionally paramount in our practices and it is the objective of Teaching, Learning and Assessment Policy and Strategy.

Faculty members, while preparing course plan for the subject, shall include the components covering authentic, reflective and collaborative learning experiences among the students. Appropriate evaluative component shall be designed and encouragements for best performers can be made.

Classroom teaching should involve students participation in the process. Sessions on Quiz, Recap on Previous session by students, Technology update by students, Rapid fire, Role Play, Mind mapping techniques, Case
Study presentation, shall be included in every lecture hour for atleast 5 minute duration.

- $\quad$ Authentic learning - Authentic learning occurs when learners engage in tasks that they are likely to encounter in the real world

Students shall be encouraged to work-in teams to replicate real-world problems and produce a credible presentation about their findings. Students will be able to control domain-specific instruments / tools.

- Reflective learning - Reflection is an intersubjective process that promotes deeper learning; it involves consciously thinking about and analyzing what one has done

Understanding assessment criteria and acting on feedback is also a way of encouraging students to reflect on what they have learned and how they will improve. At the end of every course, we can examine about learning outcome of the course is attained.

- $\quad$ Collaborative learning - Collaborative learning is an educational approach that involves groups of learners working together to solve a problem, complete a task, or create a product.

Students shall be encouraged to undergo mini-project work in teams. Problem shall cover the subjects taught during the semester. Faculty to guide batches for completion of the project work.

C. Usage of Information and Communication Technology in Teaching and Learning

It is a well known fact that not a single teacher is capable of giving up to-date and complete information in the subject. Information and Communication Technology can fill this gap because it can provide access to different sources of information. It will provide correct information as comprehensive as possible in different formats with different examples.

Classroom teaching should be augmented by innovative practices that encourages usage of NPTEL, MOOCs, Computer Based Tutorials etc. in every course plan as mandate. Usage of Virtual labs for advanced learning shall be encouraged.

\section{Project Based Learning}

Problem solving is the heart of Engineering. It's time to tackle myths like project-based learning is mostly fluff and not academically rigorous. Hence, by supporting authentic learning, promoting reflective and collaborative student involvement, PBL for every theory strengthening practical exposure to the subject is proposed for better understanding of the concepts.

Unlike conventional teaching, PBL starts with a problem and requires the student to analyze and apply information and theory learnt to solve it. Students work in groups or teams to solve or manage the assigned work.

Students very much excited about their project work and rarely they go through current engineering areas to come up with good ideas. This need to be nurtured and encouraged by Institutions. Students shall be introduced

\section{JEËF}


with project work for every subject right from III semester onwards.

For every course in the curriculum, project work in batches shall be practiced. This will trigger many innovations, new products and applications. This process, which enhances students' knowledge enables them to acquire skills like collaboration, communication and independent learning, prepares them for lifelong learning and the challenges ahead.

\section{A. Scope}

An engineer should be a designer, thinker, innovator and systems integrator. Hence, the educational system should inculcate into a student various aspects like engineering design, standards and practices, research methodologies, modeling and optimization capabilities, systems analysis and integration techniques.

PBL is a collaborative learning approach in which students actively explore real-world problems, challenges and acquire a deeper knowledge in their respective domain. A vigorous encouragement of higher order thinking and information skills, e.g. problem-solving, access, organization, interpretation and communication of knowledge can be inculcated through PBL.

\section{B. Proposed Module on PBL}

In addition to the Final-sem Project work scheduled in the University Curriculum, Institutes shall also practice project work for every course learnt during their study.

Encouragement shall be made to the student groups to identify and develop project applying the concepts learnt from the subject. Faculty members shall suggest project work specification in the course plan which should be circulated to all students in the beginning of the semester itself.

Project work shall be simulation / fabrication / development / design based and should be completed during the semester itself. Assessment can be integrated seamlessly into PBL. It is necessary to monitor the student understanding level from the beginning to end of the project.

Institutes shall encourage best student batches with critical thinking skills from every branch and promote them for professional enhancements. Innovative Promotion Schemes providing awards to the best projects shall be practiced at the institution level and Best projects shall be awarded.

\section{Preliminary Work for Final Sem Project work.}

Currently, Final sem project work by students normally focused as an academic ritual. Student just spends few days during final year study on project work, from which exploring the required skills in project work lacks.

Project work should be emphasized to synthesize knowledge from various subjects learnt during the entire course period and creatively apply it to real life situations. Inter-disciplinary projects involving two or more disciplines into the activity of creating something new across boundaries shall also be encouraged

Formation of batches, Identification of Guide based on domain chosen for project work, problem identification, literature survey, feasibility analysis, zeroth review presentation shall be completed in Seventh semester itself. Design and Implementation shall be made during Eight semester. Innovative projects shall be encouraged and appropriate support for patents for eligible profiles shall be made.

\section{Broader Outcome of PBL}

The advantage of students working upon real or simulated situations is that real problems do not have simple solutions, but require comparison and analysis of resources, strategies and costs. What the PBL approach does is facilitate a dialogue between the student, tutor, and peers (and in some cases external parties), which helps the individual make sense of their learning. Outcomes are:

- Be acquaint with identifying application of every subject

- Build competencies essential for Engineers

- Enjoyable and effective learning experience

- Practical knowledge

- Magnify impact of Engineering potential into the young minds and contribute in building the nation.

\section{Sustaining Initiatives for Enhanced Learning}

A. Imparting Industrial Exposure For Pre-Final Year Students

PBL can be augmented through In-House training for students during their pre-final year study period. Students shall be encouraged to stay at industries for a period of week and learn about industrial practices to support their project work. Exhaustive rapport building with industries is essential for institutions to seek permission for such an initiative.

\section{B. Industry-Institute Interaction}

Industries as a group and academic institutes as another group should work together to improve the employability situation. Engineering institutes in the southern part of the country fair better when it comes to industry-academia tieups, a survey conducted by CII and AICTE has revealed.

It is paramount for the industry to work closely with educational institutions to integrate market evolution with curriculum and gain knowledge-partnership. Region wise, industries shall support possible activities giving opportunities not only to tier-I institutions but also to tierII institutions. Institutions in turn will help industries by producing quality, employable graduates.

Following activities shall be initiated

- Internship Programme (Summer, Winter)

- Industrial visits

- Collaborative Project works 


\begin{tabular}{|l|l|l|}
\hline Criteria & $\begin{array}{l}\text { Agree } \\
\text { (in \%) }\end{array}$ & $\begin{array}{l}\text { To little } \\
\text { extent } \\
\text { (in\%) }\end{array}$ \\
\hline $\begin{array}{l}\text { Creativity and Innovation essential for } \\
\text { Engineers }\end{array}$ & 96 & 4 \\
\hline $\begin{array}{l}\text { Contribution to society through } \\
\text { technical skills }\end{array}$ & 92 & 8 \\
\hline Thirst of implementing learnt concept & 83 & 17 \\
\hline $\begin{array}{l}\text { Like to undergo project on interested } \\
\text { area }\end{array}$ & 92 & 8 \\
\hline Interested to develop project on own & 91 & 9 \\
\hline $\begin{array}{l}\text { Like to Enjoy challenges in developing } \\
\text { project }\end{array}$ & 93 & 7 \\
\hline $\begin{array}{l}\text { Like to learn new Technology / } \\
\text { SW/Tool }\end{array}$ & 95 & 5 \\
\hline $\begin{array}{l}\text { Comprehensive learning on } \\
\text { background techniques, existing work } \\
\text { carried in identified project area is } \\
\text { essential? }\end{array}$ & 86 & 14 \\
\hline $\begin{array}{l}\text { Like to undergo In-House Project at } \\
\text { our College if facility provided? }\end{array}$ & 74 & 26 \\
\hline Individual Attention required & 91 & 9 \\
\hline
\end{tabular}

- Orientation programme

C. Planning For PBL- Teacher End Through Faculty Visit To Factory Scheme

It is essential for faculty members to make students understand about the various advantages and opportunities that they can acquired through systematic and planned execution of the project work in the specified time frame.

PBL changes faculty members traditional role through framing the learning, helping students develop ideas, and encourage them for developments. This can be fruitfully made through faculty acquiring latest practices adapted at industries.

Faculty members shall be motivated to visit industries during semester end and update themselves to support students. This will also help institutes to bridge the gap between academic curriculum and industry practices thereby required skills can be imparted to students during their study period. Students can also face the industry expectations with confidence.

Faculty members visiting the Factory/Industry will explore basic details about the organization, Products manufacture /services provided, Certifications, Health \& Safety practices, Extension activities, Source of Energy, SDLC, ERP / Tool used. Faculty will identify possibility of campus recruitment, Expert nomination for technical events and other suitable Industry-Institute tie-up activities.

\section{Professional Societies Activities}

Professional societies shall play a vital role in enhancing quality in education through various programmes organized periodically. Experts shall be invited from National level institutes delivering latest technologies to students. Programme tapping students technical skills, leadership qualities, innovations shall be organized periodically. Every students should be enrolled for a suitable professional society and participate in skill enriching activities organized by the institute under professional society banner.

\section{Survey On Project Work - Student Expectations}

Keeping in mind to identify student expectations on project work, a survey was conducted. Total of 461 participants (pre-final year students) participated in the survey. Branchwise participant details are: CIVIL -42, CSE-99, ECE -164, EEE-49, IT-62, MECH -45. Circuit branches totaling 374 and non-circuit branches totaling 87 .

\section{Table 1. Summary on the findings based on the choices opted for queries listed.}

A. Survey Findings

Students are interested in doing society relevant project on their own through the skills acquired during course period. They show eager in doing in-house projects solving problem on their own and wish to start their work from pre-final year study. They also expect faculty to support them during project development stages.

Circuit branch students show thirst in updating their design and programming and hardware skills. Students in major show confidence in implementation. Non-circuit branch student are eager in updating their design and planning skills. Their interest towards fabrication and gaining programming skills is little lesser. This findings is based on the answers given by the students belonging to Engineering Institution at rural background. Accountable number of student strength belongs to first-generation graduate category and are interested in contributing to the society.

Student expects faculty to give technical guidance throughout the project development phases. Two-third of the group wanted to start project work during third year itself. They are interested in doing comprehensive learning on background techniques, existing work carried in their identified project area. Student willingness in doing Inhouse project work will be made successful through facilities support. Student should be refrained strictly from getting readily available projects and completing the Project work as a mere academic routine.

\section{Recommendations}

Learning expectations for career and technical education have risen significantly, largely in response to the increasing sophistication of modern careers that are demanding higher levels of education, training, and skill from the workforce. There should be more practical work to complement theory. Gap between the classroom and the industry should be bridged by skill acquisition approaches supported by industries. Student In-House Training scheme should be strengthened to meet up with its objective. Faculty to update with latest technologies, 
industrial practices. Appropriate infrastructural facility to be provided at educational institutions to support innovations, real-time projects.

\section{Conclusion}

An engineer can become a thinker, creative person or innovator only if he is allowed to independently put together all aspects of learning to solve a practical problem and look at alternatives. While internship allows them to learn engineering practices that are executed in the technical world, tutorials and laboratories allow them to demonstrate engineering in the small, only project work gives them the opportunity to become a problem solver or an innovator. Hence, project work is a very important constituent of our engineering curriculum. It is necessary to understand the role and importance of project work with real learning in the professional world.

\section{Reference}

[1] Anil R.Sahu, Dr.R.L.Shrivastava, Dr.R.R.Shrivastava, "Key factors Affecting the Effectiveness of Technical Education - An Indian Perspective", Proceedings of the World Congress on Engineering 2008, Vol.II WCE 2008, July 2-4 2008, London UK.

\section{Web Resources}

http://wwwdaseinfo.com

http://www.mhrd.gov.in/technical-education-2

http://www.deccanchronicle.com/140618/nation-

education/article/five-iits-ranked-among-top-20-brics-

universities

https://www.net.educause.edu/ir/library/pdf/ELI3013.pdf

https://www.sheffield.ac.uk/lets/toolkit/learning/reflective 